\title{
TECHNICAL AND ECONOMIC ASPECTS OF MUNICIPAL ENERGY PLANNING
}

\author{
C. BRANDONI ${ }^{1} \&$ F. POLONARA ${ }^{2}$ \\ ${ }^{1}$ Università telematica e-CAMPUS, Italy. \\ ${ }^{2}$ Dipartimento di Energetica, Università Politecnica delle Marche, Italy.
}

\begin{abstract}
The present paper analyzes the technical and economic aspects of municipal energy planning, assessing the contribution coming from different energy-saving measures in terms of greenhouse gas (GHG) emission reduction, and estimating the local authorities' investment necessary to foster climate change mitigation. Results are based on three municipal energy plans developed for urban areas located in Marche Region with a number of inhabitants ranging from 5,000 to 100,000. Different aspects of municipal energy management connected to urban size have been investigated. The public administration role has been analyzed in detail in order to identify the determinant factors for municipal energy market involvement.

Various opportunities and measures can be undertaken by municipalities to steer the energy system in the right direction, such as building codes, administration simplification, information campaigns and pilot projects aimed at reducing the public administration expenditure and also driving changes in the private sectors. The following barriers to municipal energy market participation have been identified: i) rules of municipal budgeting with debt limit, ii) difficult access to non-budgetary sources and iii) lack of human resources dedicated to energy-related issues. Several energy-saving measures have been analyzed for both public and private sectors such as: i) thermal insulation and introduction of photovoltaic (PV) power generation in schools, ii) introduction of micro-combined heat and power (CHP) system as well as geothermal energy in residential sector, iii) CHP systems in the industry sector. Factors suitable for the analysis of urban areas characterized by similar parameters (climate condition, urban density, socio-economic indexes) have been found out. Results reveal that an efficient local energy planning is able to achieve, at least, a $10 \%$ reduction of the energy demand, thus helping the achievement of the ambitious EU's 2020 targets. In particular, the main contribution is expected to come from low-carbon measures in the industry and residential sector.
\end{abstract}

Keywords: energy policy, energy savings, micro-CHP, municipal planning, renewable.

\section{INTRODUCTION}

A new energy policy strategy for 2011-2020, containing new legislative initiatives and relative proposals, is still under discussion within the European Union (EU) Commission. In particular, such discussion process started with the publication of the stocktaking document 'Towards a new Energy Strategy for Europe 2011-2020' in March 2010 [1]. EU countries are expected to achieve the ambitious EU's 2020 targets and show the world their leadership role in climate change mitigation. Five priority areas have been highlighted for the future energy policy: i) leadership in technological innovation, ii) modern integrated grid, iii) progress toward a low-carbon system, iv) a strong and coordinated external policy to improve relations with producers, consumers and transit countries as Russia, Ukraine, Mediterranean and African countries, v) availability of affordable and sustainable energy for citizens.

A main role in implementing the EU energy policy proposals can be played by local authorities, in particular by progressing toward establishing a low-carbon system and increasing citizen's awareness about environmental and energy issues. As a matter of fact, over a half of the greenhouse gas (GHG) emissions are generated in and by the cities, $80 \%$ of energy is consumed in the cities [2] and local authorities can take advantage of a direct connection to citizens.

Several energy-saving opportunities and interesting measures can be taken by the municipality to steer the energy system in the right direction, such as building codes, administration simplification, 
information campaigns and pilot projects, in order to reduce the public administration expenditure and driving changes also in private sectors.

Municipal planning has been part of the energy policy scenario for several years in many countries. In Sweden [3], for example, in 1977 a non-compulsory law encouraged local authorities to develop local energy plans; in Italy, in 1991, urban areas with more than 50,000 inhabitants were required to develop municipal programs for a rational exploitation of renewable energy. Even in the USA, where the Kyoto protocol has not been ratified yet, many cities have set important GHG emission targets [4]. New York City, among others, has set itself the target of reducing energy consumption and GHG emission generated from the city's municipal buildings and operation by 30\% by 2017 [5].

National energy policy guidelines can be set in concrete by local energy planning. In the last years, several 'bottom up' initiatives have demonstrated the important contribution coming from local energy initiatives, such as Agenda 21 and the 'Covenant of Majors' [6], an agreement jointly signed so far by more than 2,000 cities, which agreed to curb the $\mathrm{CO}_{2}$ emission by at least $20 \%$. The increase of local jobs and citizens' quality of life is another important goal of this ambitious initiative.

Although most authors [7,8] agree on the importance of local energy planning, some critical factors have been identified such as: i) the incapability to influence decision-makers in comparison with other issues such as national subsidies and taxes, ii) the difficulty to develop energy-saving initiatives due to a scarcity of human and financial resources and iii) the existence of law constraints.

In order to overcome the critical issues described above, the work focuses on technical and economic aspects of local energy policy, with particular regard to the role of public administration. Factors, which are determinant for municipal involvement in energy market and low-carbon initiatives, have been found out.

Furthermore, the work aims at quantifying the contribution of significant and repeatable 'bottom up' energy-saving actions in terms of primary energy-saving and GHG emission reduction, as well as assessing the investment required. Several initiatives for both private and public sectors have been considered and analyzed from a techno-economic and environmental point of view, such as: i) the introduction of combined heat and power (CHP) generation based on useful thermal demand, suitable for the industry and the service sector (swimming pool, great distribution organization); ii) generation of electricity from renewable sources (solar energy, biomass); iii) thermal insulation of private and public buildings, such as schools; iv) introduction of micro-CHP generation in the residential sector.

The work is based on data coming from three municipal energy plans, two of which have already been analyzed in a previous work of the same authors [9]. Municipal plans were developed for urban areas located in Marche Region, in the center of Italy, characterized by a number of inhabitants ranging from 5,000 to 100,000 , in order to investigate critical aspects connected to the public administration size. The three municipalities investigated represent a good example of the Regione Marche population distribution among very small (Corinaldo, 5,167), small (Senigallia, 44,207) and medium-sized (Pesaro, 93,488) cities.

\section{PLANNING PROCESS}

Different techniques and tools can be used to develop energy planning [10], such as multi-criteria decision techniques, Delphi surveys and specific models such as MARKAL able to develop mediumterm strategies. However, in any case every analysis starts with a territorial diagnosis and incorporates a GHG emission reduction target definition.

Figure 1 shows the flow of the methodology we have proposed for the development of local energy planning. The first step is the territorial diagnosis that analyzes the local energy supply and demand of the three main sectors: i) residential, ii) industrial and iii) tertiary, in order to identify criticalities in energy end-use. Data come from both official reports and 'ad hoc' energy audits. 


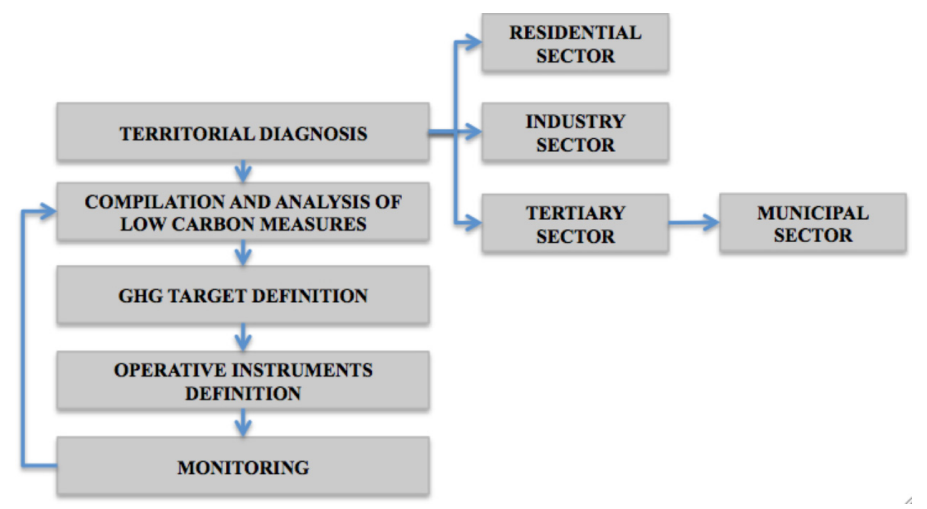

Figure 1: Local energy planning phases.

As previously introduced, particular attention has been paid to municipal ownership. The second step identifies the low-carbon actions. Each initiative has been assessed from a technical, environmental and economic point of view in order to measure the potential primary energy reduction, the consequent emission reduction and the investment required. The analysis of operating costs and potential savings in operating costs is also necessary to correctly evaluate the profitability of each energy-saving initiative. The present paper focuses on the assessment of the investments, while a more detailed economic analysis has been developed in a previous work by the same authors [9]. On the basis of the analysis developed a GHG emission target is defined.

The further step in local energy planning is represented by the identification of policies and instruments necessary to correctly apply the low-carbon initiative studied. The final step is the monitoring phase that starts an iterative process to modify, improve or add new countermeasures.

\section{TERRITORIAL DIAGNOSIS}

In the Marche Region, inhabitants are almost equally distributed in very small, small and medium urban areas. Figure 2 shows that $40 \%$ of people live in municipalities with less than 10,000 inhabitants, $31 \%$ live in areas characterized by a number of inhabitants ranging from 10,000 to 50,000 and $29 \%$ in areas ranging from 50,000 to 100,000 inhabitants. Developing municipal planning for all urban area categories could make the achievement of regional energy policy target easier. Three municipalities, Corinaldo, Senigallia and Pesaro, belonging to each urban size category, have been analyzed in order to evaluate their local energy policy and to analyze the different aspects of the municipal energy management in relation to urban size. The main data characterizing the urban areas analyzed are reported in Table 1.

Figures 3 and 4, respectively show the percentage sector shares in electric and thermal demand for the areas analyzed. As shown in the graphs, the dimension of the area does not affect the energy distribution, which essentially depends on socio-economic parameters.

Per capita electric and thermal consumption of different economic sectors have been reported in Table 2. Values might be used to have an order of magnitude of energy consumption of urban areas characterized by similar parameters such as climate, energy distribution and socio-economic values.

As far as the thermal consumption is concerned, the residential sector appears to be crucial for all the areas analyzed. In order to understand the reasons, in Fig. 5, we have reported the number of buildings by year of construction. More than $80 \%$ of buildings in all the areas analyzed were built before 1991. The first law about energy efficiency was introduced in Italy in 1976, followed by 


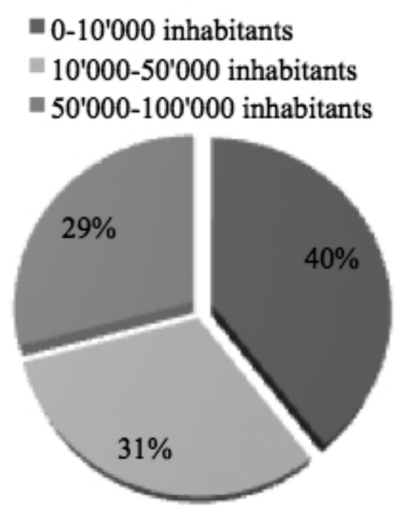

Figure 2: Percentage of inhabitants classified by urban area size.

Table 1: Characteristic parameters of the urban areas analyzed.

\begin{tabular}{lccc}
\hline & $\begin{array}{c}\text { Corinaldo Very } \\
\text { small urban area }\end{array}$ & $\begin{array}{c}\text { Senigallia Small } \\
\text { urban area }\end{array}$ & $\begin{array}{c}\text { Pesaro Medium } \\
\text { urban area }\end{array}$ \\
\hline Inhabitants (n) & 5,167 & 44,207 & 93,488 \\
Dwellings (n) & 2,055 & 20,913 & 38,637 \\
Workers in tertiary sector (n) & 1,315 & 11,011 & 26,752 \\
Workers in industry sector (n) & 621 & 4,796 & 11,393 \\
Urban density (person/m ${ }^{2}$ ) & 107 & 359 & 720 \\
Build-up area/inhabitants (m²/person) & 39 & 34 & 38 \\
\hline
\end{tabular}

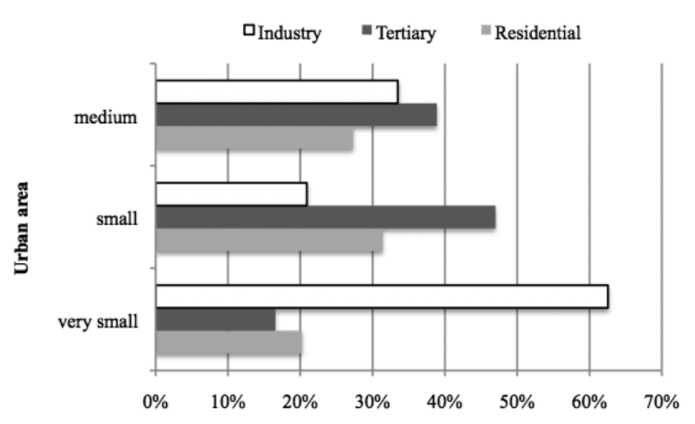

Figure 3: Electricity consumption. 


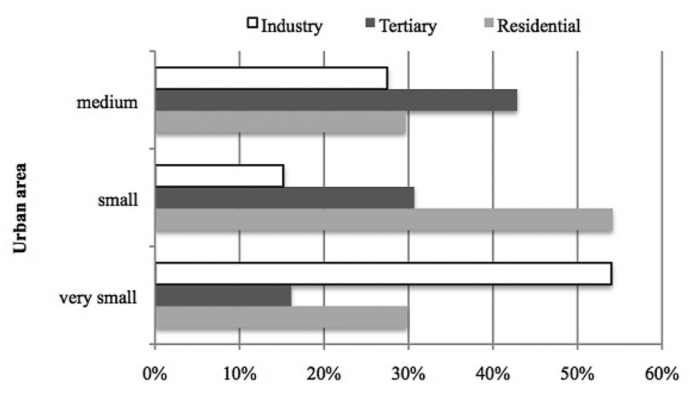

Figure 4: Thermal consumption.

Table 2: Per capita consumption of the three areas analyzed.

\begin{tabular}{|c|c|c|c|}
\hline & $\begin{array}{l}\text { Residential sector } \\
\text { (toe/person) }\end{array}$ & $\begin{array}{c}\text { Tertiary sector } \\
\text { (toe/person) }\end{array}$ & $\begin{array}{l}\text { Industry sector } \\
\text { (toe/person) }\end{array}$ \\
\hline & \multicolumn{3}{|c|}{ Electric energy demand } \\
\hline Very small urban area & 0.5 & 0.6 & 5.1 \\
\hline Small urban area & 0.4 & 1.2 & 1.3 \\
\hline \multirow[t]{2}{*}{ Medium urban area } & 0.5 & 1.0 & 2.1 \\
\hline & \multicolumn{3}{|c|}{ Thermal energy demand } \\
\hline Very small urban area & 0.6 & 0.29 & 0.5 \\
\hline Small urban area & 0.9 & 0.25 & 0.4 \\
\hline Medium urban area & 1.2 & 0.23 & 3.1 \\
\hline
\end{tabular}

Electric energy demand has been calculated at 0.187 toe/MWh [12].

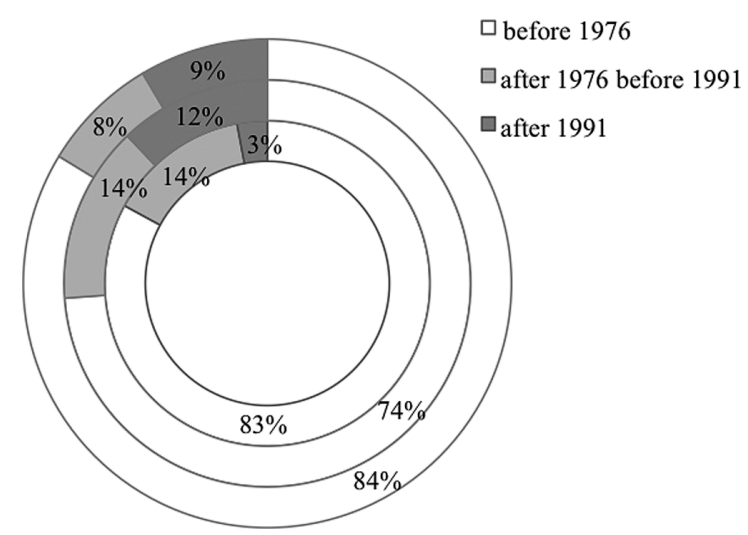

Figure 5: Percentage number of building per year of construction. 
another important law in 1991. Table 3 provides the energy consumption of buildings as a function of the year of construction reported in a regional survey [11].

The smallest area shows the lowest per capita thermal demand, although $83 \%$ of dwellings were built before 1976. An additional survey has revealed that $34 \%$ of buildings have been restored from 1992 to 2009, paying attention to energy-saving upgrade, thanks to loans and grants offered by the central government.

Eventually, the public sector has been analyzed in detail; the percentage of electric and thermal consumption by end-users is reported in Figs. 6 and 7. Schools are responsible for more than 50\% of thermal consumption in all the areas analyzed, suggesting that thermal insulation in schools can effectively reduce municipal expenditure.

Table 3: Primary energy consumption of dwelling sector [11].

\begin{tabular}{lc}
\hline Date of construction & Primary energy consumption $\left(\mathrm{kWh} / \mathrm{m}^{2}\right)$ \\
\hline Before 1976 & 227 \\
1976-1991 & 182 \\
After 1991 & 170 \\
\hline
\end{tabular}

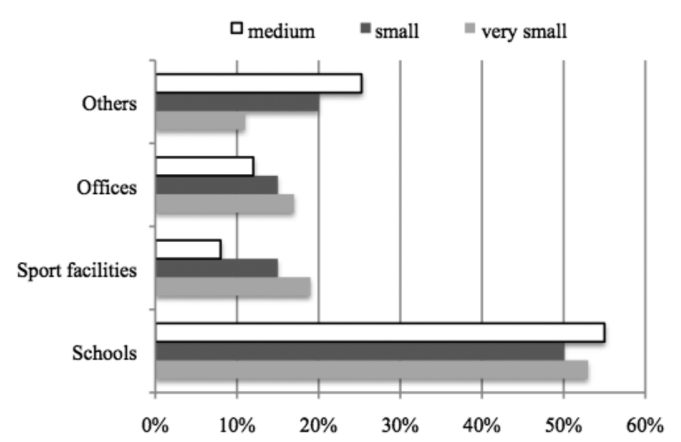

Figure 6: Thermal consumption in public sector.

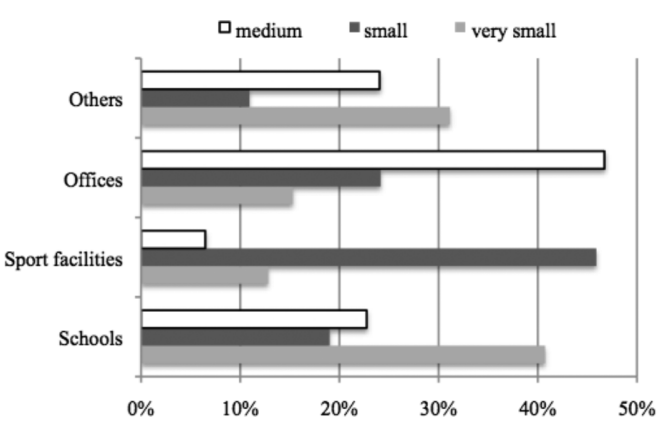

Figure 7: Electric consumption in public sector. 
Table 4: Per capita consumption of the public sector.

\begin{tabular}{lccc}
\hline & Very small area & Small area & Medium area \\
\hline & Per capita thermal consumption (toe/person) \\
Schools & 0.009 & 0.007 & 0.009 \\
Sport facilities & 0.003 & 0.002 & 0.001 \\
Offices & 0.003 & 0.002 & 0.002 \\
Others (theater, rest homes, etc.) & 0.002 & 0.003 & 0.004 \\
& Per capita electricity consumption (MWh/person) \\
Schools & 0.024 & 0.009 & 0.014 \\
Sport facilities & 0.008 & 0.021 & 0.004 \\
Offices & 0.009 & 0.011 & 0.028 \\
Others (theater, rest homes, etc.) & 0.008 & 0.005 & 0.014 \\
Public lighting & 0.090 & 0.100 & 0.100 \\
\hline
\end{tabular}

Table 4 provides information about per capita consumption for different end-uses in the areas analyzed. Per capita electric consumption of public lighting is the main responsible for electric consumption in all the areas analyzed, and is about $0.1 \mathrm{MWh} /$ person.

\section{LOW-CARBON MEASURES}

The present paragraph deals with significant and repeatable actions studied for the residential, the tertiary and the industry sectors. First of all, we have proceeded to evaluate the primary energy reduction derived from energy-saving actions; then, we have analyzed the feasibility of the same actions, taking into consideration applicability factors based both on literatures and the authors' experience. However, more detailed information about economic aspects can be found in the previous work developed by the same authors [9].

The GHG's emission reduction has been calculated using an emission factor of 3 tonCO 2 /toe, on the basis of the actual savings assessed.

\subsection{Residential sector}

Several initiatives were studied for the residential sector: i) thermal insulation actions for buildings built before 1991, ii) adoption of legislative decree no. 192/2005 of 19 August 2005 in the existing municipal buildings' codes aiming at reducing the primary energy consumption of buildings, iii) information campaign for high-energy efficiency household equipment, iv) replacement of electric boilers with solar collector systems, v) introduction of micro-CHP devices and vi) introduction of geothermal heat pump in dwellings.

As already quoted in the analysis phase, the residential sector is the main responsible for thermal consumption, mainly due to a lack of an accurate thermal insulation buildings design. The potential reduction of primary energy has been calculated using factors coming from regional surveys [11], according to which the energy reduction of dwellings built before 1976 and 1991 results to be of 108 and $77 \mathrm{kWh} / \mathrm{m}^{2} /$ year, respectively. On the basis of the average size of dwellings in the urban areas analyzed $\left(107,89\right.$ and $\left.101 \mathrm{~m}^{2}\right)$ and considering an applicability factor of $10 \%$, the primary energy consumption reduction has been calculated. Results are provided in Table 5. The second 
Table 5: Primary energy reduction and GHG emission reduction.

\begin{tabular}{|c|c|c|c|c|c|c|}
\hline & \multicolumn{2}{|c|}{ Very small } & \multicolumn{2}{|c|}{ Small } & \multicolumn{2}{|c|}{ Medium } \\
\hline & $\begin{array}{l}\text { Primary } \\
\text { energy } \\
\text { reduction } \\
\text { (toe) }\end{array}$ & $\begin{array}{c}\text { GHG } \\
\text { emission } \\
\text { reduction } \\
\left(\text { ton } \mathrm{CO}_{2}\right)\end{array}$ & $\begin{array}{l}\text { Primary } \\
\text { energy } \\
\text { reduction } \\
\text { (toe) }\end{array}$ & $\begin{array}{c}\text { GHG } \\
\text { emission } \\
\text { reduction } \\
\left(\text { tonCO }_{2}\right)\end{array}$ & $\begin{array}{l}\text { Primary } \\
\text { energy } \\
\text { reduction } \\
\text { (toe) }\end{array}$ & $\begin{array}{c}\mathrm{GHG} \\
\text { emission } \\
\text { reduction } \\
\left(\text { tonCO }_{2}\right)\end{array}$ \\
\hline $\begin{array}{l}\text { Thermal } \\
\text { insulation }\end{array}$ & 170 & 509 & 1,055 & 3,166 & 3,261 & 9,782 \\
\hline Solar collector & 16 & 49 & 177 & 530 & 671 & 2,013 \\
\hline New construction & 6 & 19 & 63 & 189 & 116 & 348 \\
\hline $\begin{array}{l}\text { High efficiency } \\
\text { equipment }\end{array}$ & 51 & 153 & 520 & 1,560 & 961 & 2,883 \\
\hline $\begin{array}{l}\text { High efficiency } \\
\text { lamp }\end{array}$ & 48 & 144 & 492 & 1,476 & 909 & 2,727 \\
\hline Micro-CHP & 20 & 60 & 202 & 607 & 374 & 1,121 \\
\hline $\begin{array}{l}\text { Geothermal } \\
\text { heat pump }\end{array}$ & 1.08 & 3 & 11 & 32 & 19.8 & 59 \\
\hline Total & 312 & 937 & 2,520 & 7,559 & 6,311 & 18,934 \\
\hline
\end{tabular}

energy-saving measure analyzed concerns new buildings. In particular, the contribution coming from the adoption of Italian legislative decree no. 192/2005 in the existing municipal buildings' codes has been analyzed. The said Italian legislative decree no. 192 (as amended by legislative decree no. 311 of 29 December 2006) implemented in Italy the Directive 2002/91/CE concerning the energy efficiency in buildings. The decree aims at improving buildings energy performances by strengthening the thermal insulation standards. Furthermore, the Italian law established additional measures such as the satisfaction of at least $50 \%$ of hot water demand by solar generation and the obligation to install $1 \mathrm{kWe}$ from renewable energy for each new unit property. It has been supposed to introduce photovoltaic (PV) power generation.

It's a general opinion that the introduction of the above-mentioned decree will effectively decrease the total energy consumption by about $30 \%$.

Another important item in residential energy consumption is represented by the electric equipment used in dwellings, considering that - according to a national study [13] - a family uses, daily, an average of $8 \mathrm{kWh}$. As a result, we have proceeded to measure the possible energy savings coming from the use of high efficiency household equipment and high efficiency lamps. With respect to this, we believe that a specific information campaign developed by municipalities could definitely help to increase the positive results.

The results are based on the data reported in a previous work and shown in Table 5 [9].

Another interesting measure studied for the residential sector is the replacement of electric water boilers with solar collector systems. As a matter of fact, although in the areas analyzed, as in all the country, an extensive natural gas pipeline network makes almost all the buildings dependent on this source for heating, tap water heating and cooking, it has been found out that a small percentage of dwellings use electric water boilers. Consequently, it has been supposed to apply flat-plane solar collectors characterized by an energy-efficiency of $32 \%$, considering 


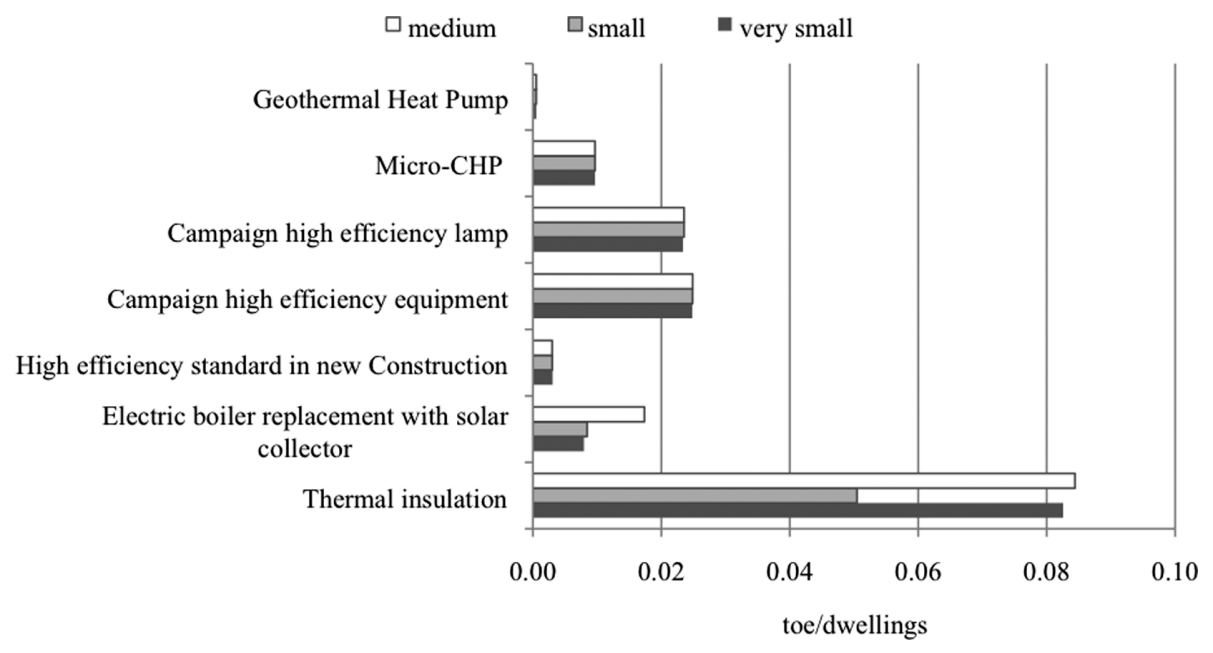

Figure 8: Energy savings per dwellings.

a solar radiation of $4.6 \mathrm{kWh} / \mathrm{m}^{2} /$ day, which determine an energy saving of 0.3 toe/year/dwelling; then, it has been assumed that $40 \%$ of electric boilers will be replaced.

Although the market of most micro-CHP technologies is still immature [14], the primary energy reduction coming from the use of a $5 \mathrm{kWe}$ internal combustion engine (ICE) has been measured. Data come from a previous work developed by the authors [15], which has evaluated the energy savings coming from the introduction of micro-CHP system in detached houses. It has been assumed an applicability factor of $5 \%$, due to a not fully developed market.

Eventually, the energy reduction coming from the use of geothermal heat pump in a small percentage (i.e. 20\%) of new dwellings has been evaluated. This technology is demonstrated to be particularly interesting when coupled with PV power generation. The standard measure is referred to a new apartment of $100 \mathrm{~m}^{2}$; it has been supposed to apply a geothermal heat pump characterized by an average coefficient of performance (COP) of 5 . Table 5 sums up the contribution coming from the initiatives studied. The results show that due to the high percentage of dwellings built before 1991, in all the areas analyzed, interesting savings may come from thermal insulation. Figure 8 provides information on the energy saving per dwellings for all the areas analyzed. Figure 9 shows the primary energy saving vis-à-vis investment costs. The replacement of electric boiler with solar collector results to be the most effective solution due to the low cost of solar panels, followed by thermal insulation. The introduction of geothermal heat pump performs better than micro-CHP, in terms of energy savings toward emission reduction, but their contribution to energy saving is lower, as a matter of fact. Micro-CHP technologies can replace the classic heat boiler [16], while geothermal heat pump can be better applied in new constructions in order to reduce the cost for boreholes.

\subsection{Service sector}

The service sector includes both private sector and public sector buildings. The private sector is characterized by different end-users in terms of energy demand, such as offices, hotels and supermarket, which are suitable for different energy-savings initiatives. 


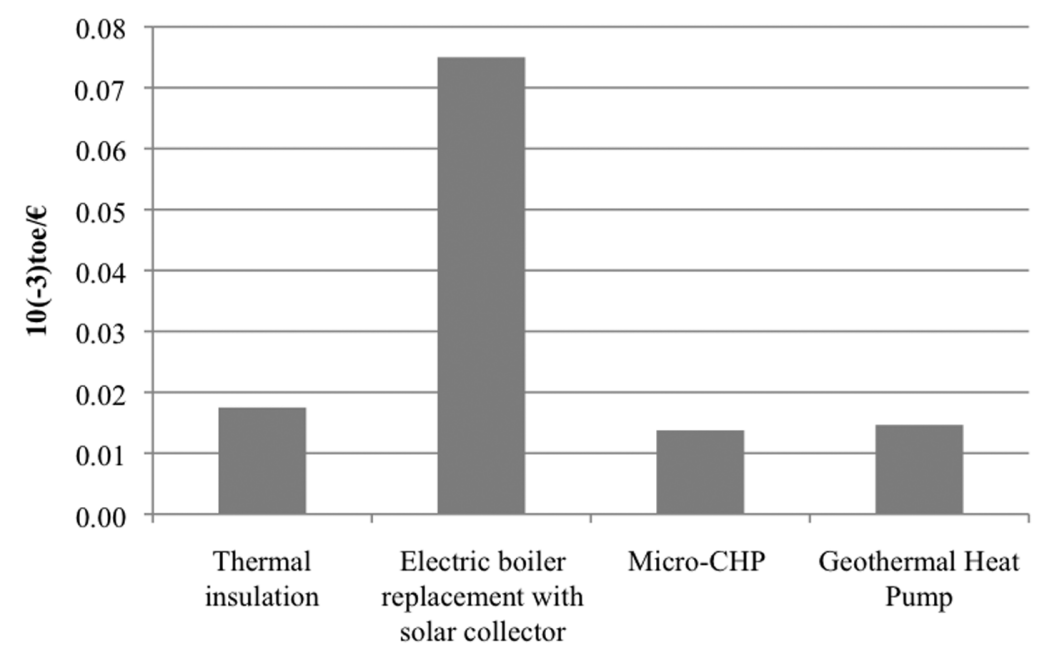

Figure 9: Energy saving (per year, per dwellings) vis-à-vis investment cost.

It has been decided to analyze two significant and repeatable measures: i) the introduction of CHP plant in private swimming pools, which can be repeated for municipal swimming pools, and ii) the introduction of distributed generation (DG) system in supermarkets.

Swimming pools result to be suitable for the introduction of CHP systems due to an important need of thermal energy during the whole year. The hypothesis was to introduce a $100 \mathrm{kWe}$ microturbine connected in parallel to the grid. Microturbines technology represents, nowadays, a potential alternative to ICE [17], particularly in the context of mini-cogeneration, compared with ICE. In fact, though they have a lower electrical efficiency and a higher initial cost, they are more compact and lightweight, they require less maintenance and they have a longer working life, thanks to a more straightforward architecture. Results are shown in Table 6.

Supermarkets are characterized by a strong demand of energy for refrigeration, for food preservation and for air conditioning during the summer.

This makes supermarkets particularly suitable for trigeneration applications with the prime mover coupled with absorption systems. Based on the results of a study developed by the authors [18], it has been assumed to introduce trigeneration systems for the production of electricity, heating and air conditioning energy combined with PV systems. The analysis has been developed on the basis of the consumption of a typical supermarket characterized by a sales area of $10,000 \mathrm{~m}^{2}$. Results are shown in Table 6.

With respect to the Municipality of Corinaldo, the smallest area analyzed, it has been decided to study possible energy-saving actions solely with reference to the municipal ownerships, given that neither private nor municipal swimming pools are located in the area and the only supermarket has been recently refurbished.

In the public sector, the following initiatives have been analyzed: i) public lighting energysaving measures, ii) thermal insulation in schools and iii) installation of PV panel in public areas. The public lighting energy-saving measures is concerned with: i) the replacement of high pressure sodium (HPS) lighting with LED (light-emitting diode) technology for outdoor application, and ii) the replacement, in traffic lights systems, of incandescent lighting with LED technology. 
Table 6: Energy savings in tertiary sector.

\begin{tabular}{|c|c|c|c|c|c|c|}
\hline & \multicolumn{2}{|c|}{ Very small } & \multicolumn{2}{|c|}{ Small } & \multicolumn{2}{|c|}{ Medium } \\
\hline & $\begin{array}{l}\text { Primary } \\
\text { energy } \\
\text { reduction } \\
\text { (toe) }\end{array}$ & $\begin{array}{c}\text { GHG } \\
\text { emission } \\
\text { reduction } \\
\left(\text { tonCO }_{2}\right)\end{array}$ & $\begin{array}{l}\text { Primary } \\
\text { energy } \\
\text { reduction } \\
\text { (toe) }\end{array}$ & $\begin{array}{c}\text { GHG } \\
\text { emission } \\
\text { reduction } \\
\left(\text { tonCO }_{2}\right)\end{array}$ & $\begin{array}{l}\text { Primary } \\
\text { energy } \\
\text { reduction } \\
\text { (toe) }\end{array}$ & $\begin{array}{c}\mathrm{GHG} \\
\text { emission } \\
\text { reduction } \\
\left(\text { tonCO }_{2}\right)\end{array}$ \\
\hline Swimming pool & & & 60 & 180 & 180 & 540 \\
\hline $\begin{array}{l}\text { Great distribution } \\
\text { organization }\end{array}$ & & & 600 & 1,800 & 600 & 1,800 \\
\hline Public lighting & 56 & 168 & 125 & 375 & 372 & 1,116 \\
\hline Thermal insulation & 9 & 27 & 105 & 315 & 800 & 2,400 \\
\hline PV panel & 80 & 240 & 795 & 2,385 & 633 & 1,899 \\
\hline Total & 145 & 435 & 1,685 & 5,055 & 2,585 & 7,755 \\
\hline
\end{tabular}

Table 7: Comparison between HPS and LED.

\begin{tabular}{llrr}
\hline & & HPS & \multicolumn{1}{c}{ LED } \\
\hline Lamp power & (W) & 150 & 40 \\
Lifetime & (h) & 10,000 & 100,000 \\
Operational hours & (h/year) & 3,500 & \\
Energy saving for each replacement & (toe/year) & 0.07 & \\
\hline
\end{tabular}

Electric energy demand has been calculated at 0.187 toe/MWh [12].

Table 8: Comparison between incandescent lamp and LED.

\begin{tabular}{llcr}
\hline & & HPS & \multicolumn{1}{c}{ LED } \\
\hline Lamp power & $(\mathrm{W})$ & 70 & 13 \\
Lifetime & $(\mathrm{h})$ & 5,000 & 100,000 \\
Operational hours & $(\mathrm{h} /$ year) & 2,900 & \\
Energy saving for each replacement & (toe/year) & 0.03 & \\
\hline
\end{tabular}

Electric energy demand has been calculated at 0.187 toe/MWh [12].

LED technology is characterized by several benefits such as longer lifetime, less maintaining needs, high color brightness and efficacy. Tables 7 and 8 compare, respectively, the sodium highpressure technology and the incandescent lamp with LED technology.

As in the residential sector, a standard thermal insulation action has been planned for schools, and it has been assessed a $30 \%$ reduction of primary energy.

The last initiative analyzed has been the introduction of PV panels in public area. Solar energy is a strategic source for the areas analyzed, such as for all the Mediterranean areas. However, the main problem connected to the introduction of PV energy in public sector is represented by the high 
Table 9: Primary energy reduction in industry sector.

\begin{tabular}{|c|c|c|c|c|c|c|}
\hline & \multicolumn{2}{|c|}{ Very small urban area } & \multicolumn{2}{|c|}{ Small urban area } & \multicolumn{2}{|c|}{ Medium urban area } \\
\hline & $\begin{array}{l}\text { Primary } \\
\text { energy } \\
\text { reduction } \\
\text { (toe) }\end{array}$ & $\begin{array}{c}\mathrm{GHG} \\
\text { emission } \\
\text { reduction } \\
\left(\text { tonCO }_{2}\right) \\
\end{array}$ & $\begin{array}{l}\text { Primary } \\
\text { energy } \\
\text { reduction } \\
\text { (toe) }\end{array}$ & $\begin{array}{c}\mathrm{GHG} \\
\text { emission } \\
\text { reduction } \\
\left(\text { tonCO }_{2}\right) \\
\end{array}$ & $\begin{array}{l}\text { Primary } \\
\text { energy } \\
\text { reduction } \\
\text { (toe) }\end{array}$ & $\begin{array}{c}\mathrm{GHG} \\
\text { emission } \\
\text { reduction } \\
\left(\text { tonCO }_{2}\right) \\
\end{array}$ \\
\hline Electric motors & 404 & 1,213 & 777 & 2,331 & 3,075 & 9,225 \\
\hline DG fuelled by natural gas & & & l & l & l & l \\
\hline DG fuelled by biomass & & & l & l & 9,000 & 27,000 \\
\hline & 404 & 1,213 & 777 & 2,331 & 12,075 & 36,225 \\
\hline
\end{tabular}

investment required to the municipality. In Section 5, the municipal capability to find budget and not-budgetary resources will be discussed.

\subsection{Industrial sector}

The use of high efficiency electric motors and the introduction of DG systems have been analyzed in order to reduce the industry energy demand. A national study found out that $70 \%$ of industry electric consumption comes from electric motors. On the basis of the results reported in a relative study [19], the potential energy savings have been calculated.

According to the study, $17 \%$ of electric motors are applied for HVAC (heating, ventilation and air conditioning), $2 \%$ of which as compressors and $83 \%$ for other applications. The potential energy reduction for each category is respectively, 35\%,15\% and 15\%. Results are reported in Table 9.

DG systems [20] offer a number of advantages, such as a reduction in the energy costs for the users as well as for the domestic and international economies as a whole, fewer losses in transmission, fewer $\mathrm{CO}_{2}$ emissions, a better quality of electricity generation and a less vulnerable electrical system. In case of contemporary demand of electric and thermal energy CHP plants have been analyzed. In detail, it has been measured the possibility to feed the CHP plants with natural gas or biomass, particularly interesting for small plants (1-2 MWel).

Biomass is a renewable energy and it is demonstrated that it gives an important contribution to GHG's emission reduction in case of 'short-chain' biomass plants, that is the maximum distance between biomass production and its use must be within $50 \mathrm{~km}$. In the smallest urban area analyzed, the energy demand is essentially an electric energy demand, consequently the introduction of CHP technology has not been considered.

\section{THE ROLE OF PUBLIC ADMINISTRATION}

The present paragraph deals with the municipal involvement in local energy policy and factors which are decisive for public administration involvement in energy market.

Local authorities have several possibilities to get involved in the energy field, such as promoting energy efficiency and renewables in municipal ownership, launching information campaigns to increase citizens' awareness upon energy issues, requiring high efficiency energy standards in new architectural projects, properly issuing construction permits. 
In order to finance low-carbon initiatives, local authorities need to find both budgetary and nonbudgetary sources, such as bank loans or third capital finance [21].

With reference to the financing side, the main problems come from the difficulty to obtain nonbudgetary resources as a result of debt-limited municipal budgeting rules introduced in Italy, as in other European countries, as a consequence of principles recognized by the Maastricht Treaty.

In detail, the debt ceiling is calculated as a function of municipal incomes (taxes, fees, national fund transfer, etc.); this means that medium urban areas, that usually guarantee a higher number of services, can count on higher incomes and, consequently, higher debt limits.

Although the above-mentioned rule is applied solely for municipalities with more than 5,000 inhabitants, very small and small urban areas, as in the cases under analysis, may have some problems.

A possible solution could be represented by an agreement with the Energy Service Companies (ESCos) that finance energy-saving initiatives. By the said agreement, the municipal institution can keep its energy costs constant whereas the ESCo maintains the ownership of the equipment until the end of the contract. In more detail, during the contract period, the municipality pays the same energy costs that it would pay in absence of the contract, but in the form of a service fee to the ESCo.

This service fee, in particular, includes the energy costs plus an equipment fee, which is financed by the ESCo. In this case, de facto, municipalities would act as borrowers; the only difficulty might derive from the absence of a successful history of cooperation with ESCos, which are not so widespread either in Marche Region or in Italy.

It is to be underlined that public administration is characterized by higher reliability than private companies since they 'never go out of business'; this is the reason why, in other European countries, such as Bulgaria and Hungary, ESCos work close to municipalities, notwithstanding bureaucratic ties that affect those countries.

Another possible solution could be not to consider the investment in energy efficiency and renewables in the calculation of municipal debt limit, as suggested by the Covenant of Mayors.

A further critical issue in municipal energy market involvement is the availability of human resources, having the time and technical skills to develop energy-saving actions.

This aspect appears to be a barrier especially for very small and small urban areas that do not have, in general, an energy task force able to coordinate energy initiatives in different sectors (city planning, environment, public work and transport department) and to catch opportunities such as joining European Programs to finance local low-carbon measures.

The outsourcing of technical support could help very small and small municipalities to clearly define short and medium targets, financed either by budgetary resources or by Regional Government Loans as for two of the cases under analysis.

The Regional Government should recommend the development of local energy planning in order to put regional energy guidelines into action.

Moreover, municipalities play an important role in steering the energy system in the right direction, using tools such as building code and information campaigns.

High efficiency requirement in new buildings can give an important contribution to energy consumption reduction and, as shown in a previous analysis $[9,22]$, they turn out to be less expensive when implemented at a planning stage.

Furthermore, energy standards defined in building codes are often used as efficiency targets for refurbishment existing buildings.

To conclude, Table 10 provides information on topics and cost of a series of information campaign able to increase citizens' investment in energy efficiency and renewables. 
Table 10: Topics and costs of information campaigns for energy efficiency and renewables.

\begin{tabular}{lrrr}
\hline Topics & Very small & \multicolumn{1}{c}{ Small } & Medium \\
\hline High efficiency lamp and equipment in dwellings & $5,000 €$ & $15,000 €$ & $20,000 €$ \\
PV power generation and solar collector in dwellings & $5,000 €$ & $15,000 €$ & $20,000 €$ \\
Energy savings opportunity in tourism facilitates & $1,000 €$ & $4,000 €$ & $8,000 €$ \\
The importance of energy auditing in industry sector & $1,000 €$ & $4,000 €$ & $8,000 €$ \\
Total & $12,000 €$ & $38,000 €$ & $56,000 €$ \\
\hline
\end{tabular}

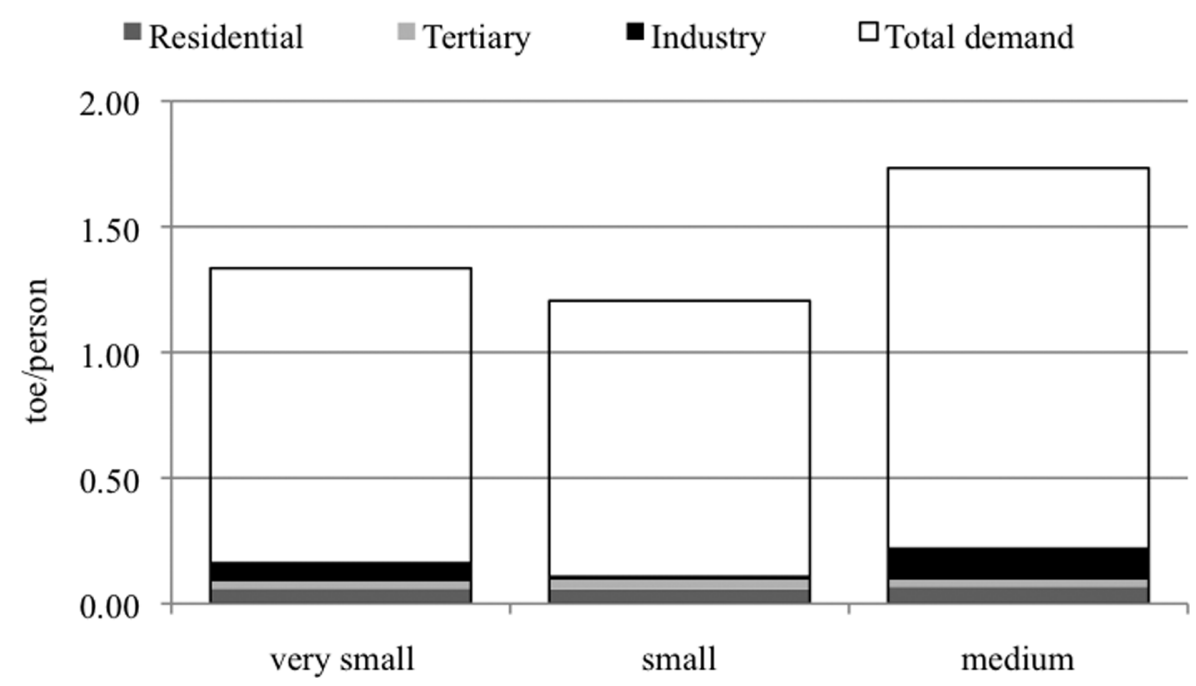

Figure 10: Per capita energy savings.

\section{CONCLUSIONS}

The present paper analyzes the technical and economic aspects of municipal energy planning quantifying the contribution coming from different energy-saving initiatives and analyzing factors which are considered to be determinant for municipality's involvement in energy market.

Per capita energy savings achievable in different economic sectors, coming from the low-carbon measures analyzed, have been reported in Fig. 10. The graph also shows urban areas per capita energy demand in order to point out its potential reduction. Results reveal the efficacy of the development of local energy planning, able to reduce more than $10 \%$ of the energy demand, and provide a consequent decrease in GHG emissions.

Determinant factors for municipal involvement in energy market have been studied and analyzed for municipalities of different size. Lack of human resources and difficulty to obtain non-budgetary resources come to affect more very small and small urban areas than medium ones. The development of local energy planning with the clear definition of short- and medium-term objectives, as well as the outsourcing of technical support and the agreement with ESCos companies can overcome the critical issues outlined. 


\section{ACKNOWLEDGEMENTS}

The authors are gratefully indebted to Corinaldo, Senigallia and Pesaro municipalities, which were the object of the analysis.

\section{REFERENCES}

[1] European Commission's Public Consultation on Towards a new Strategy for Europe 2011-2020. http://ec.europa.eu/energy/strategies/consultations/doc/2010_07_02/2010_07_02_energy_ strategy.pdf

[2] Kamal-Chaoui L., Robert A., Competitive Cities and Climate Change. OECD Regional Development Working Papers $N^{\circ}$ 2, 2009. http://www.oecd.org/dataoecd/30/36/44232251.pdf

[3] Olerup B., Scale and scope in municipal energy-planning in Sweden. Journal of Environmental Planning \& Management, 43(2), pp. 205-225, 2000. doi: http://dx.doi. org/10.1080/09640560010676

[4] Byrnea J., Hughes K., Rickerson W., Kurdgelashvili L., American policy conflict in the greenhouse: Divergent trends in federal, regional, state, and local green energy and climate change policy, Energy Policy, 35(9), pp. 4555-4573, 2007. doi: http://dx.doi.org/10.1016/j. enpol.2007.02.028

[5] Best energy management practices in 13 North American Municipalities, http://www.cec.org/ municipalenergy/docs/New York City.pdf

[6] Covenant of majors committed to local sustainable energy, http://www.eumayors.eu/mm/staging/library/com_lt_lang/docs/Texte_Convention_EN.pdf

[7] Stenlund Nilsson J., Martensson A., Municipal energy-planning and development of local energy-systems, Applied Energy, 76, pp. 179-187, 2003. doi: http://dx.doi.org/10.1016/S03062619(03)00062-X

[8] Gomi K., Shimada K., Matsuoka Y., A low-carbon scenario creation method for a local-scale economy and its application in Kyoto city, Energy Policy, 38, 4783-4796, 2010. doi: http:// dx.doi.org/10.1016/j.enpol.2009.07.026

[9] Arteconi A., Brandoni C., Bartolini C.M., Polonara F., Assessment of local energy policies impact in reducing GHG emissions, Proc. of the 3rd International Conference on Environmental Economics and Investment Assessment, eds K. Aravossis, C.A. Brebbia, WIT: Cyprus, pp. 51-62, 2010. doi: http://dx.doi.org/10.2495/EEIA100051

[10] Terrados J., Almonacid G., Perez-Higueras P., Proposal for a combined methodology for renewable energy planning. Application to a Spanish region, Renewable and Sustainable Energy Reviews, 13, pp. 2022-2030, 2009. doi: http://dx.doi.org/10.1016/j.rser.2009.01.025

[11] Principi P., Di Perna C., Fantini L., Fioretti R., Ruffini E., Serpilli G., Valutazione energetico ambientale di edifici di edilizia pubblica residenziale di diversa tipologia ed ubicazione. Regional survey, 2003.

[12] Decision no. 3/08 of the Italian Electricity and Gas Authority. Updating of the conversion factor of the $k W h$ to toe in relation to the mechanism of the energy efficiency certificates.

[13] Italian National agency for New technologies, Energy and sustainable economic development, Rapporto energia e ambiente, National survey, 2007-2008.

[14] De Paepe M., D’Herdt P., Mertens D., Micro-CHP systems for residential applications, Energy Conversion and Management, 47, pp. 3435-3446, 2006. doi: http://dx.doi.org/10.1016/j. enconman.2005.12.024

[15] Arteconi A., Bartolini C.M., Brandoni C., Energy and economic analysis of small-scale distributed generation in the residential sector, Proc. of the 14th International Stirling Engine Conference and Exhibition, Groningen-The Netherlands, 2009 (16-17 November). 
[16] Macchi E., Campanari S., Silva P., La microcogenerazione a gas naturale, Polipress, Milano, 2005.

[17] Kaikko J., Backman J., Technical and economic performance analysis for a microturbine in combined heat and power generation, Energy, 32, pp. 378-387, 2007. doi: http://dx.doi. org/10.1016/j.energy.2006.06.013

[18] Arteconi A., Brandoni C., Polonara F., Distributed generation and trigeneration: Energy saving opportunities in Italian supermarket sector, Applied Thermal Engineering, 29, pp. 1735-1743, 2009. doi: http://dx.doi.org/10.1016/j.applthermaleng.2008.08.005

[19] Italian manufacturing and service companies' organisation. Proposals for Italy's extraordinary plan for energy efficiency and energy saving, National report, 2009.

[20] Chicco G., Mancarella P., Distributed multi-generation: A comprehensive view, Renewable and Sustainable Energy Reviews, 13, pp. 535-551, 2009. doi: http://dx.doi.org/10.1016/j. rser.2007.11.014

[21] Rezessya S., Dimitrov K., Urge-Vorsatz D., Baruch S., Municipalities and energy efficiency in countries in transition Review of factors that determine municipal involvement in the markets for energy services and energy efficient equipment, or how to augment the role of Municipalities as market players, Energy Policy, 34, pp. 223-237, 2006.

[22] Verbeeck G., Hens H., Energy savings in retrofitted dwellings: economically viable? Energy and Buildings, 37, pp. 747-754, 2005. doi: http://dx.doi.org/10.1016/j.enbuild.2004.10.003 